\author{
Stanko Gerjolj* \\ University of Ljubljana, Slovenia
}

\title{
The Challenges of Education in a One Child Family- from the Perspective of Abraham's Biblical Story
}

In Slovenia the proportion of one-child families is $48.6 \%$ and that with two children is $42.5 \%{ }^{1}$. A similar trend can be seen in many other European countries. The theory and moreover, the practice of educational activities are faced with new challenges, challenges not known in the past. Both from the parents' perspective

* STANKO GERJOLJ - CM, PhD in theology (Innsbruck 1986) and pedagogy/psychology (Innsbruck 1995), full professor at the Faculty of Theology of the University of Ljubljana since 2012. From 1993 to 1996 he worked as a school psychologist in the counseling department of the Catholic High school in Ljubljana. In the period from 2008 to 2012 he was the Dean of the Faculty of Theology of the University of Ljubljana. His scientific research and teaching are in the areas of psychology of education, especially in connection with the teaching of humanistic, ethical and religious contents. He is especially interested in Gestalt pedagogy, where he obtained the title of a Gestalt trainer in 2001 and Gestalt supervisor in 2004. In Slovenia he is a member of the Society for University Didactics, of the National Society of Psychologists, of the Expert Council of the Republic of Slovenia for Education and more. In the international sphere he is a member of the European Catholic Theologians, of the Team of European Catechists, and from 2005 to 2012 he had been the Chairperson of the International Society for Integrative Gestalt pedagogy. He has published 4 scientific monographs (two in German) and over 70 scientific papers and articles. He has participated in several research projects on the national as well as on the international level and has been visiting lecturer e.g. in Innsbruck and Graz (Austria), Regensburg (Germany), Pula (Croatia), Skhoder (Albania), Tuzla (Bosnia and Herzegovina), and Ružomberok (Slovakia).

$1 \quad$ N. Vertot, Ob mednarodnem dnevu družin, in: Rebublika Slovenija, Statistični urad Rebublike Slovenije, http://www.stat.si/novica_prikazi.aspx?id=1617 (07.03.2014). 
as well as from the child's viewpoint, raising one child differs from that of raising two children or larger families.

A two-child family provides at least some peer communication and thus existential social education, while in the one-child family the child communicates exclusively with the parents. Typically an only child communicates very well with adults but finds it much more difficult to enter into communication with members of his/ her own generation. This is especially noticeable when it involves entering into ongoing intense relationships with peers. The excuse that kindergarten children make friends and learn to communicate with their peers stands on shaky ground because such socializing cannot be compared to daily living and interacting with siblings. In kindergarten, children can change friends; this logic does not work at home with siblings. It is the perseverance in relationships, which enable us to sustain lasting relationships/This can be a weakness of contemporary family life. Characteristically, at present we can rather quickly establish relationships but we have much more difficulty in maintaining them.

In addition to weak social support and lack of partnership education, the parents of a one-child family are particularly challenged as to how to release the child's emotional attachment to them and thus be able to develop healthily and achieve independence. The well-known story of Abraham's sacrifice of his son Isaac clearly demonstrates how dramatically parents can experience the process of separation, and freeing their children, especially their only child.

From a pedagogical perspective, Abraham's story, where God calls and asks him to sacrifice his son, speaks of the natural conflict between parents and children when the latter grow up. Abraham, in this extremely tense and dynamic story, represents both mothers and fathers as they accompany their children on the steep, uncertain and difficult journey of maturation. Isaac represents sons and daughters in the process of growing up.

Abraham experiences his son Isaac's growing up so dramatically that he feels like God is stealing Isaac and even wants to destroy him. But in fact, this story presents a test of Abraham's liberating faith, which he discovers only at the end of this dramatic process, even though he always lives in faith and acts out of faith ${ }^{2}$. God wants Isaac to grow up and become autonomous. Therefore, he must "be ripped” from his father's (and mother's) hands. In this manner, God forces parents to entrust their son or daughter to God.

2 L. Powell, W. R. Self, Holy Murder: Abraham, Isaac, and the Rhetoric of Sacrifice, Lanham - Boulder - New York - Toronto - Plymouth 2007, University Press of America, p. 44. 
After a long period of time, Abraham and Sarah, on the one hand, almost gave up their expectations for descendants and thus their longing for a child lessened; on the other hand, the long years of searching and creating a common way purified their mutual relationship. They relaxed and subsequently they were given the gift of their son Isaac. Undoubtedly, in such circumstances, there exists a danger of possessive relationships, which creates additional conflicts and tensions. Obviously in the case of Abraham, who, in accordance with God's promise, yearns for many descendants, there is no difference. Therefore, God challenges and tests him. God knows that people can arrive at the most profound and basic life lessons only if "it hurts". On the physical, psychological and religious level the story of Abraham and Isaac illustrates how difficult and demanding the work of separation and maturation is for both generations: parents and children. In this dramatic pedagogical process 12 key moments or stages which help father and son (or mother and daughter) to achieve a level of maturity and where they both become capable of an independent life, can be detected,

1. The process of an adolescent growing up starts with prepuberty ${ }^{3}$, which predicts an interesting initial formulation ${ }^{4}$. One period ends, and then the Bible introduces us to a new chapter". "Some Years Later" represents a transition between two relatively independent and different chapters, but it is the writer's plan to connect them ${ }^{6}$. If we take into consideration that the transition is more pronounced than in other cases we can come to the conclusion that the Bible desires to prepare the reader for an unusually dramatic and emotionally complex story, which will follow ${ }^{7}$. Thus, at the beginning of the text we assume that there is a specific focus depicting how Isaac ceased to live as a child and begins to behave as a youth beginning puberty. Also, the available data support the belief that in this story the relationship between father and son during the period of the son's growth and development is

\footnotetext{
3 S. Gerjolj, Živeti, delati, ljubiti, Ljubljana 2009, Celjska Mohorjeva družba, p. 70.

4 "Some years later God decided to test Abraham". Gen 22:1.

5 L. Powell, W. R. Self, Holy Murder: Abraham, Isaac, and the Rhetoric of Sacrifice, Lanham

- Boulder - New York - Toronto - Plymouth 2007: University Press of America, p. 8.

$6 \quad$ N. J. Cohen, Self, Struggle \& Change: Family Conflict Stories in Genesis and Their Healing Insights for Our Lives, Woodstock1995, Jewish Lights Publishing, p. 80.

7 E. J. Hartley, New International Biblical Commentary: Genesis, Peabody, Massachusetts \& United Kingdom 2000, Hendrickson Publishers, Paternoster Press, p. 206.
} 
particularly important ${ }^{8}$. The whole context suggests that Abraham wishes to finally have a more "normal" and relaxed life", but it seems that this is not the wish of God who immediately places Abraham in a new crisis.

It is interesting that, already at the beginning of the journey, God announces that this is a test, which is actually the purpose of pre-puberty. On one hand, the Bible may also be trying to relax the reader and insinuate a happy ending; on the other hand, with accentuated drama God's test becomes real life ${ }^{10}$. God does not play games with people; instead God tests and educates. Therefore, God places Abraham, the "father of faith", in totally realistic but equally in very dramatic circumstances. Abraham is not only a disciple of God, but also our teacher, who speaks to us not only on the cognitive, but also on a very experiential level ${ }^{11}$.

2. "Here I am" is the basic response and it represents the "alphabet" of parents' attitudes and behaviors regarding their children during adolescence. Thus, at the beginning of Isaac's dramatic changes God calls Abraham, and, thereby, also calls every other father or mother.

Parents can easily recall unique examples of their child's challenging reactions in puberty, reactions, which the parents have not seen before. Thus, during this period of adolescence children become an additional medium through which God calls, addresses and teaches parents and educators. Perhaps Abraham, especially in such a challenging puberty for Isaac, recognizes God's call. When he discovers the first signs of change regarding his son's behavior he responds immediately and turns to God. Abraham wants to be in God's presence and resolve the conflictual situations that he foresees with God.

8 At the time of the sacrifice Isaac was between the ages of twenty and thirty. Abraham was a little over one hundred years old. Despite the the symbolism of numbers it is believed that Isaac was, at that time, already a strong young man. E. J. Hartley, New International Biblical Commentary: Genesis, Peabody, Massachusetts \& United Kingdom 2000, Hendrickson Publishers, Paternoster Press, p. 209, 211; J. V. McGee, Genesis: Chapters 16-33, Nashville 1991, Thomas Nelson, p. 71.

9 H. J. Walton, The NIV Application Commentary: From biblical text ... to contemporary life. Grand Rapids, Michigan 2001, Zondervan, p. 517.

10 L. Powell, W. R. Self, Holy Murder: Abraham, Isaac, and the Rhetoric of Sacrifice, Lanham - Boulder - New York - Toronto - Plymouth 2007: University Press of America, p. 8.

11 H. J. Walton, The NIV Application Commentary: From biblical text ... to contemporary life. Grand Rapids, Michigan 2001, Zondervan, p. 514. 
When God called father Abraham, he responded without hesitation answering: "Here I am, Lord" (Gen 22: 1b). This places him at God's disposal ${ }^{12}$. With this reply, he also gives a message to his child regarding his basic stance. Abraham's stance is that he will not leave God despite the weight of the trials.

"Here I am" is the answer which adolescents most desire and expect from their parents, no matter how trivial or provocative the questions they ask ${ }^{13}$. For example, a father might be cleaning his "beloved" car when his daughter arrives with her questions and thus pulling him away from his work. If the father replies: "Just a moment, when I finish washing the car I will have enough time to answer your questions", most likely the daughter will begin to walk away from him and she will close herself off from her father, especially if such answers are repeated. Of course, the daughter could talk to him before or after the car wash but she chooses to challenge her father when he is occupied. This is typical of a pubescent's nature and children have a right to challenge their parents in this way. They act intuitively and not in a deliberately rude and disrespectful manner. In this case, the daughter attempts to verify what is more important to the father - his daughter or his car. She will not be satisfied that while he continues to wash his car he tells her that she means the most to him. Instead she will provide many challenges giving her father the opportunity to back up his words. During adolescence, children test their parents more than parents test their children.

If a father leaves his work to devote himself to his daughter, and if she does not recognize that he is not playing a game with her, she will most likely allow him to complete his work and then she will speak with him later. If, however, the father gives her the impression that she interrupts him and that he has no time for her because his car, despite his words, means more to him than his daughter, she may still provoke him for a period of time but then she will shut down and bring her life issues and problems to her "buddies".

Behind each pubescent question lies a hidden longing for the fundamental response: "Here I am" for you and without conditions. At this moment, nothing and no one is more important than you. It is important for parents to give them this answer when they need it and long for it. Despite opposite reactions, pubescents are attached to their parents and they love them greatly. At the same time, they

12 N. J. Cohen, Self, Struggle \& Change: Family Conflict Stories in Genesis and Their Healing Insights for Our Lives, Woodstock1995, Jewish Lights Publishing, p. 81-82.

13 S. Gerjolj, Živeti, delati, ljubiti, Ljubljana 2009, Celjska Mohorjeva družba, p. 75. 
also desire to be greatly loved by their parents - more than a "car". Adolescents don't intend to be rude. They only want unconditional parental love.

Thus, when we respond to a child: "Here I am", it is the same answer we give to God. Children are not our property but gifts from God.

3. It is not uncommon that parents perceive a feeling of fear regarding their children during the process of growing up ${ }^{14}$. When Abraham says his "fiat" to God and to his son Isaac, their mutual Calvary of maturation was just starting. He experiences the whole situation as a directive from God: "Go get Isaac, your only son, the one you dearly love! Take him to the land of Moriah, and I will show you a mountain where you must sacrifice him to me on the fires of an altar" (Gen 22:2).

This divine order is enormously challenging, dramatic and emotional.

God tells Abraham that this directive is not meant for any other child but for his son, his only son. Abraham feels that if he loses Isaac his whole life will be destroyed. In particular regarding the promises, which relate to numerous descendants, it is understandable that Abraham understands and accepts God's challenges with difficulty. However, God continues to escalate the tension and evokes in Abraham's mind all the love and joy that he has had as a father with his child ${ }^{15}$.

As a father to sacrifice Isaac, "your son, your only son, whom you love most"? How?

By killing?

Is this possible?

Yet this is the scenario that befalls many fathers/mothers today, perhaps even more frequently than in the past.

Consider the addiction centers where, for example, drug addicts gather. If a father with his son walks by young people using drugs, who are maybe a few years older than his child, and who no longer know whether they are still alive or already dead, is he not intimidated by the question: "What if in a few years I have to look here for my own son?" And the answer? ... Only not that! I prefer to "kill" him rather than see him suffering like that. This scenario is too cruel to be true. Yet, its cruelty arises just because it can happen at any time.

14 This is a similar feeling to Jesus in the Garden of Gethsemane, when he asked his Father to let this cup pass from him. Lk 22:42a.

15 E. Benyoetz, Keine Macht becherscht die Ohnmacht, in: B. Greiner, B. Janowski, H. Lichtenberger (Eds.), Opfere deinen Sohn!, Tübingen 2007, Francke Verlag, p. 126. 
In this way, God educates Abraham - not wishing him pain and suffering, but because God wants Abraham to do everything to ensure that his son will not end up in the environment of a subcultural death.

4. Timely decision making is a move that overcomes the fear of pragmatic avoidance and the escape from demanding challenges ${ }^{16}$. Despite a difficult test and a possible temptation to protect his son for a period of time from Calvary due to the growing up process, Abraham acts early in the morning, that is, as soon as he observes the first puberty changes in Isaac ${ }^{17}$.

It is interesting that Abraham does not ask God any question nor does he enter into any argument or demand an explanation. His belief in God is so strong that he trusts God unconditionally ${ }^{18}$. His inner willingness for an unconditional communication with God, where he is ready to learn, is seen by the fact that he immediately responds to God's invitation. Often, in similar circumstances, God calls a person twice but Abraham, unreservedly and with a strong positive response, answers the first call ${ }^{19}$.

5. Abraham initiates his son Isaac's process of socialization in the adult world. He takes two servants with him. In the light of today's world, these two servants can be seen as two adult family friends who can be trusted by both father and son ${ }^{20}$. For the very first time in his life, during his journey of growing up, Isaac finds himself interacting with adults and thus, together with his father, he prepares himself for adulthood. They discuss life issues while traveling along the steep path of maturing.

Father Abraham worries about how this will end. He even prepares himself for the most painful option, which is illustrated by the preparation of wood for the burnt offering. This can be understood as the accumulation of open, unresolved

16 Also at this stage Abraham is close to Jesus, who immediately added: “... not my will, but yours be done". Lk 22:42b.

17 Thus, Abraham got up early the next morning and chopped wood for the fire. He put a saddle on his donkey and left with Isaac and two servants for the place where God had told him to go. Gen $22: 3$.

18 J. Krašovec, Nagrada, kazen in odpuščanje: Mišljenje in verovanje starega Izraela v luči grških in sodobnih pogledov, Ljubljana1999, Slovenska akademija znanosti in umetnosti, p. 107.

19 E. J. Hartley, New International Biblical Commentary: Genesis, Peabody, Massachusetts \& United Kingdom 2000, Hendrickson Publishers, Paternoster Press, p. 206.

20 Seen from the perspective of relatability in modern times Abraham's journey to the mountain symbolizes not only fathers and sons, but also mothers and daughters. We can imagine a mother with her daughtor who start the growing up process supported by two women friends. 
issues, conflicts and other difficulties. One can think of Isaac's reckless teenage reactions and actions which, if necessary, Abraham can use as a means of coercion and control of his son when he runs out of other arguments. Therefore he takes with him all burdensome material, which means that we cannot think of an idyllic and relaxed dreamy talk about how to become an adult; the conversation is real, concrete and probably even conflictual.

6. The process of early puberty socialization is apparently coming to an end and Isaac enters the critical period of adolescence. On the third day of their common journey, which can be labeled as a socialization process and which includes talks, prayer, reflection and meditation, Abraham realizes what is involved in accompanying an adolescent son. He has an inkling of how this journey will end as he sees from a far the place or the purpose of their final destination ${ }^{21}$.

Three days have symbolic meaning ${ }^{22}$ and announce that time is necessary to know how to grasp or comprehend something. To deal with one issue for three days means that we come to the depth of that issue and that we know and understand it as much as possible ${ }^{23}$. On the third day socialization ends and Abraham feels the need to modify communication ${ }^{24}$.

On one hand Abraham's directions to his servants to leave them alone to travel, can be seen as the moment when Abraham is "fed up" with Isaac's complicated process of growing up and his adolescent challenges and thus, concludes that he would prefer to talk to Isaac individually to tell him what he needs to hear. On the other hand, the Bible does not stretch the story but rather slightly discharges it by suddenly announcing a happy ending.

Theoretically, there is an interpretation of Abraham's announcement of a "happy ending" as an expression of fear that Isaac would resist him, break communication

21 Three days later Abraham looked off in the distance and saw the place. Gen 22:5.

22 L. Powell, W. R. Self, Holy Murder: Abraham, Isaac, and the Rhetoric of Sacrifice, Lanham - Boulder - New York - Toronto - Plymouth 2007: University Press of America, p. 14.

23 In the Bible this measure of time occurs several times. For three days, for example, Jonah lived in the body of the whale and thus, he discovered both distress and the richness of solitude (Jn 2:1-11). Joseph and Mary searched three days for Jesus and experienced what "losing" a child and living without him means but at the same time they were preparing a place for joy when they later found him in the temple ( $\operatorname{Lk} 2: 46)$. Jesus was in the tomb for three days where he actually experienced and conquered death (Mt 27:63-64; Lk 24:7).

24 He told his servants, "Stay here with the donkey, while my son and I go over there to worship. We will come back". Gen 22:5. 
or run from the conflict. Nevertheless, the entire composition exceeds such a simplified explanation. Moreover, every adolescent is able to quickly "read" such a strategy. Adolescents are very much aware when parents "play" and when their requirements are serious. Abraham does not sell cheap strategies. However, in his vision of how to grow up, there are visible signs of a deep "hope against hope". It is the deepest religious attitude of one who believes and hopes, even when there are no tangible reasons to do $\mathrm{so}^{25}$. Yet, Abraham carries the hope that cooperation with God simply "must" result in a good finish. Without a doubt, on the existential level, Abraham is additionally sensitized and encouraged through his holistic relationship with God, which helps him, at least occasionally, to better understand and trust Isaac more. We can conclude that after three days of common travel and discussions regarding life issues, Abraham's negative scenario is abandoned and his hope of a good and happy ending is strengthened. Instead of speaking of sacrifice he speaks of prayer.

7. Personal dialogue or talking face-to-face is the second most important form of communication in adolescence. Abraham notices that Isaac changes from an aggressive teenager into a sensitive adolescent. Thus Abraham feels the need to talk with his son face-to-face. The fundamental mysteries of life are more easily communicated and articulated through confidential personal discussions. Since these conversations are frequently conflictual, Abraham, in a timely manner, senses the influence of servants. If a conflict occurs between father and son, it is likely that the servants would intervene in the quarrel. In such a situation, father and son would need to adapt to external and public influence and they would not dare to say everything they feel in their hearts.

Abraham clearly identifies Isaac with the sacrifice ${ }^{26}$, who is forced to dig a grave for himself or at least who takes an active part in this action. Further dialogue between father and son indicates that Isaac has a premonition regarding what is happening and what to expect.

Abraham wants Isaac to carry the firewood, which symbolizes unresolved, complex and conflictual issues ${ }^{27}$. The father does not wish to be burdened all his

25 L. Powell, W. R. Self, Holy Murder: Abraham, Isaac, and the Rhetoric of Sacrifice, Lanham - Boulder - New York - Toronto - Plymouth 2007: University Press of America, p. 44.

26 E. J. Hartley, New International Biblical Commentary: Genesis, Peabody, Massachusetts \& United Kingdom 2000, Hendrickson Publishers, Paternoster Press, p. 208.

27 L. Powell, W. R. Self, Holy Murder: Abraham, Isaac, and the Rhetoric of Sacrifice, Lanham - Boulder - New York - Toronto - Plymouth 2007: University Press of America, p. 16. 
life with his son's problems. Isaac will use them to create the foundation for the altar on which his own life will be threatened. This situation is not unusual. In most instances, adolescents through provocation provide major threats primarily to their own lives.

The father carries the hot coals and the knife, two symbols, which very likely express both the father's feelings about the path they have traveled as well as past talks. The father remembers what he advised and recommended to his son but feels a burning and pain in his heart because he feels that his son did not listen. Thus, each of them travels on his own way of maturation, each of them carrying an individual burden: the father with burning and painful concerns (hot coals and knife) and the son with yet unspoken but burdensome issues (wood $)^{28}$.

Both communicate with caution since they have close at hand hot coals and a knife - symbols of fear, fright, power and violence. Even Isaac overcomes the tensions of pubescent aggression and respectfully presents the problem, saying: "Father, we have the coals and the wood, but where is the lamb for the sacrifice?" (Gen 22:7) There is so much pain, so many problems and open questions. Where is the lamb? Where is the solution?

After somehow removing the lump from his throat, the father responds: "God will help us find a solution" 29 . At that moment Abraham's heart did not allow him to say to Isaac that he will be the lamb of sacrifice ${ }^{30}$. Speaking in this manner, Abraham's response is understood by some biblical scholars as an "exit in an emergency", which reconnects Abraham with his very first hope that God will somehow and somewhere find a solution ${ }^{31}$.

A lump in the throat is an important aspect of communication, even though it is not mentioned in the story. A reader, capable of reading the text on a deep level, is able to feel the text and is somehow unable to continue reading it. Adolescent issues can surprise us and if we take them seriously, many questions or comments are hard to "swallow". Without a lump in his throat Abraham's words could be interpreted as avoiding the question rather than providing a serious answer.

28 Abraham put the wood on Isaac's shoulder, but he carried the hot coals and the knife. Gen $22: 6$

29 "My son", Abraham answered, "God will provide the lamb". Gen 22:8a.

30 A. Höfer, Gottes Wege mit den Menschen: Ein gestaltpädagogisches Bibelwerkbuch, München 1993, Don Bosco Verlag, p. 121.

31 L. Powell, W. R. Self, Holy Murder: Abraham, Isaac, and the Rhetoric of Sacrifice, Lanham - Boulder - New York - Toronto - Plymouth 2007: University Press of America, p. 17. 
Often we provide quick answer to a difficult issue, saying: "God will help you". Many times with such a pious and superficial response we avoid a serious conversation. With adolescents, it is better to not try this way, because they will immediately detect our tactic. This does not mean that young people reject God's help; it means that we need to take conversations with young people seriously and that we initially do what we are capable of doing. Before offering comfort by using the words: "God will help you", we need to explore all other available answers. Otherwise adolescents will object and oppose us. Their rebellious responses are absolutely necessary and provide for us a way to prove that we love them despite their opposition and objections. Abraham's response can be interpreted in the words of the proverb: Help yourself and God will help you.

8. Silence and eye contact during the period of adolescence is the first and primary form of communication, which is shown in the communication between Abraham and Isaac. We may assume that since their last conversation, while walking a long way to reach the top of the mountain ${ }^{32}$, Abraham and Isaac apparently walk more or less in silence ${ }^{33}$. This does not lessen the intensity of their mutual relationship, rather the opposite ${ }^{34}$. Silence does not mean that they have nothing to say to one another, but rather, it suggests that their mutual relationship became so deep and, at the same time, tense and intense that it is possible to maintain it only in silence. They intensively think of each other while sensing that their individual burden cannot be spoken. In fact, every additional word can be a threat toward increasing the destabilization of their relationship.

9. The culmination of the conflict is the moment that is needed by everyone, even those travelling the gentlest journey to autonomy and non-violent independence. It is the "cutting of the umbilical cord", the second birth, a birth of an independent and responsible life, which must be attained.

Silence as an active stance in conflictual situations sooner or later increases the stress to a degree that it "must" achieve the purification of an outburst even if the form of the outburst is mild. Thus, in this story, conflict between father Abraham and his son Isaac reaches its peak and this opens questions from which

32 The two of them walked on. Gen $22: 8 \mathrm{~b}$.

33 A. Höfer, Gottes Wege mit den Menschen: Ein gestaltpädagogisches Bibelwerkbuch, München 1993, Don Bosco Verlag, p. 121.

34 E. J. Hartley, New International Biblical Commentary: Genesis, Peabody, Massachusetts \& United Kingdom 2000, Hendrickson Publishers, Paternoster Press, p. 208. 
the father cannot escape ${ }^{35}$. In his most sincere communication in front of God does Abraham, who represents the father with undisputed authority, see his adolescent son a competitor who threatens his power? Does Abraham, in his stance of being threatened, use God's help and God's authority to tie and master his increasingly dangerous rival? How can God allow all this or even require it?

Maybe we are not able to accept the harshness that flashes and thunders from these stories, but running away is not a solution. Viewing these stories as something that happened long ago and believing that today is different, is an easy consolation which distances us even more from the real issues of the growing up process. Today, reality is not significantly different. Modern education is in many instances gentler, but it follows the same principles and laws.

Adolescents know that they are dependent on their parents and that they "must" obey and follow their requirements. They are aware that, with authoritarian parents, arguing is not successful. The parents have in their hands "the hot coals and the knife", this means sufficient tools to master their "children" ${ }^{\text {". }}$. Therefore, in everyday life when adolescents are at home, in so-called closed conditions, they usually blindly obey and do not present major challenges and provocations to their parents. Yet, contrary to their external docile demeanor, they accrue anger and aggressiveness, which they more or less successfully conceal.

Youths know the psychology of the parents better than the parents think. Despite their growing anger they wait for the right opportunity. On such occasions, as when someone visits the family, the adolescents target and challenge the parents. Parents want to be and to be seen as good educators, generous and understanding towards their children and they do not want to be embarrassed in front of the visitor. But since the "child" continues to challenge and refuses to stop, it sometimes happens that the parents "boil over". Then the visitor and the circumstances are forgotten and the parents scream uncontrollably at the child: "As long as you live under my roof, you will obey my rules!” or something similar.

35 When they reached the place that God had told him about, Abraham built an altar and placed the wood on it. Next, he tied up his son and put him on the wood. He then took the knife and got ready to kill his son. Gen 22:9-10.

36 This is probably Abraham's position because through the story Isaac speaks only once and, even on this occasion, his words are imbued with much fear. E. Hartley, New International Biblical Commentary: Genesis, Peabody, Massachusetts \& United Kingdom in 2000, Hendrickson Publishers, Paternoster Press, p. 205. Isaac does not argue with his father but he is satisfied with an unclear answer, which is unusual for pubescents. 
The above situation is an example of a moment when we raise the knife over our child. Regardless of the presence of a visitor, we roughly give a message to the "child" that he/she can be mastered whenever and however we want.

Yet, the adolescent has reached the intended goal, because she/he probably wanted our uncontrolled explosion. He/she wanted to make the growing up process transparent and she/he succeeded. If in the adolescent's nature there is a touch of cynicism, he/she will then begin to ask childish questions, which will embarrass us again. With that behavior we are told: "If you want me to stay a child, well, then I will just be a child".

By building an altar, Abraham hints at justifying how much he wants the best for his child. Abraham's fear, which is increasingly transformed into aggression and attack, is wrapped in cellophane, symbolized by an altar of good intentions. However, Isaac's idealized image of his father collapses. On the altar of conflicts and tensions Isaac inadvertently learns the true image of his father and, only with God's help, which just in time stops his father from violence, he can accept it. It should be noted that similar adventures and experiences are an integral part of the growing up process. Such events in individual cases are not tragic but could become tragic if we do not learn from them and merely unconsciously repeat them ${ }^{37}$.

37 A few years ago, I had a meal with an unnamed family and when I entered the home, I noticed that the table was set with four place settings. However, only three of us, an older woman, her husband and myself, sat down to eat. We started the meal. After a while, without saying a word nor extending a greeting a somewhat neglected middle-aged man, sits down and begins to eat. The conversation ceases and the woman in particular appears embarrassed. I had a feeling she did not know what to say. Finally she said: "This is my son. His name is Marko". After the polite greeting, the conversation starts, but Marko continues to be somehow absent. In a good mood his mother boasts that he is somehow diligent, that he obeys and recently even tells them where he goes and when he will return. Into this pleasant atmosphere she tosses out: "But he also could be married by now." Without considering the consequences, I rhetorically asked: "Did you tell him this when he was eighteen?" Talk again fades, and the resulting silence is more torturing than that experienced by Marko's arrival. Only then I realized what I said ... Obviously this is a case where the Marko's parents for too long and too frequently "lifted the knife" and "tied" him. In so doing, the parents gave him the message that he was still a child and that they did not want to lose him. Actually they did not lose him because he is still a child. Marko still tells his parents everything; often he asks something and most of the time he obeys ... but he did not get married ... if he married ... and left the alcohol ... and the cigarettes ... if he completed school ... got a job ... or at least worked at something, everything would be fine ... but then he would no longer be a child. 
10. God as an educator is also a great dramatist. At the moment of Abraham's violent outbreak God sends him redemptive insight, which opens a new perspective on his and his son's life. Immediately after the action, in fact, already during it, Abraham realizes what he is doing. He remembers God's call and relives it. God calls him again. In his conscience he feels the call stronger than ever. This time God, through the angel who symbolizes the inner voice of conscience ${ }^{38}$, calls him twice $^{39}$. It is evident that Abraham is so focused on his own world that even in conflictual situations responds so automatically, that he ignores God's first call; this requires the angel to call Abraham a second time, thus providing a stronger "shake" .

Abraham's conscience call stirs and reminds him of the promise he made to God at the beginning of Isaac's process of maturing. Intuitively and spontaneously he repeats: "Here I am!" The fact that Abraham hears God's voice and replies with a fundamental positive response is a key moment that changes the course of the story ${ }^{41}$. In practice, these are the moments of which parents are most afraid. Such moments are very demanding because they require parents to change. The basic response: "Here I am", already indicates change in a person. In actuality the angel, in his instruction, merely articulates the content already felt and known by Abraham. In such decisive moments God motivates more than directs.

Abraham flinches, realizes and acknowledges that Isaac is no longer a child. More vigorously than in the period of fear, Abraham discovers that God does not want Isaac for God's own sake ${ }^{42}$. Nevertheless, God wishes that Abraham releases Isaac and allows him to grow up. God tells him that Isaac is no longer his child, but a person who will soon become independent and who will no longer pursue only

38 H. Schulweis, For those who can't believe, New York 1994, HarperCollins, p. 124.

39 But the Lord's angel shouted from heaven, "Abraham! Abraham!" "Here I am!" he answered. Gen 22:11. At the beginning of the story when God decides to test Abraham God calls him only once. Gen $22: 1$.

40 N. J. Cohen, Self, Struggle \& Change: Family Conflict Stories in Genesis and Their Healing Insights for Our Lives, Woodstock1995, Jewish Lights Publishing, p. 83-84.

41 "Don't hurt the boy or harm him in any way!" the angel said. "Now I know that you truly obey God, because you were willing to offer him your only son". Gen 22:12.

42 B. Willmes, Die Prüfung Abrahams nach Gen 22,1-19, in: H. Hoping, J. Knop, T. Böhm (Eds.), Die Bindung Isaaks, Paderborn - München - Wien - Zürich 2009: Ferdinand Schöningh, p. 51. 
the plans and expectations of the parents ${ }^{43}$. Abraham realizes that he will destroy his son if he possessively limits and ties him into a child's stance. Thus, as a result of this dramatic event they both grow: Abraham as a father and Isaac as a son ${ }^{44}$.

11. This educative drama, of course, is not over. God transmits to Abraham some important insights: which can be called a "renouncement of possessiveness" and a "capacity to listen" 4 .

When Abraham notices a ram in the bush he becomes aware of what it means to be a father of an adolescent son ${ }^{46}$. The ram in this story represents a horned animal, and colorfully illustrates typical adolescent behavior.

Horned animals do not flourish in a soft environment where they cannot sharpen their horns. Also, a too hard or too rough environment is also not good for them, because they can break their horns. Bushes, therefore, offer just the right resistance and represent a healthy environment for "horned animals".

If we transfer this simple symbolism in the context of the adolescent growing up process, we discover that neither a too soft nor a too hard upbringing is healthy. During the period of adolescence a good educator is one who can familiarize him/ herself with the role of the bushes and attest to it in practice. In the "bushes" the ram, this means the adolescent, has the final word. He doses out the pressure and he challenges others regarding resistance. Sharpening the horns never hurts the ram, but always damages the bushes. If the ram is in pain because of resistance, he can terminate sharpening his horns and change his communication strategy.

Soft bushes, that rapidly break or can be walked on, are neither appropriate nor interesting for young people. It isflexible bushes which are 'appropriate' and which offer a non-violent and not too painful resistance but one capable of challenging the ram. Flexible busheseven after being damaged, consistently return to their original position. In this manner, flexibility testifies to a quality of education, which includes both consistency as well as the capacity to make agreements.

43 In a similar situation, when Jesus is 12 years old, he says to his parents: "Why did you have to look for me? Didn't you know that I would be in my Father's house?”. Lk 2:49.

44 L. Powell, W. R. Self, Holy Murder: Abraham, Isaac, and the Rhetoric of Sacrifice, Lanham - Boulder - New York - Toronto - Plymouth 2007: University Press of America, p. 19.

45 B. Willmes, Die Prüfung Abrahams nach Gen 22,1-19, in: H. Hoping, J. Knop, T. Böhm (Eds.), Die Bindung Isaaks, Paderborn - München - Wien - Zürich 2009, Ferdinand Schöningh, p. 57.

46 Abraham looked up and saw a ram caught by its horns in the bushes. So he took the ram and sacrificed it in place of his son. Gen 22:13. 
It is true that adolescents criticize and insult us for imposing restrictions and establishing requirements saying that we are outdated, rigid and without understanding, etc. In their words, we are anything but good parents and educators. However, it is exactly through agreements, responsible limits and requirements that we tell them that we care for them. The greatest sign of our love for adolescents is that we continue to love them even when, through their insults, they nail us to the cross. Of course, this doesn't mean that parents should endure all things silently. However, it is helpful to know that in such moments the heart of unconditional love is revealed. Adolescent criticism and insults are not an explosion of hostility or rudeness, but they are a test of our love and inner stability.

Bushes, therefore, advise us to be flexible in making agreements, setting norms and requirements and that we maintain consistency regarding rules. If, despite the contract, adolescents break the agreements, none of the consequences will be too difficult for them, especially if the consequences have been agreed upon in advance. By showing respect and taking the agreed-upon-rules into consideration adolescents earn freedom and trust. Freedom not earned is not appreciated. Only freedom, which is worked hard for and fought for, is valued. The way of maturing is demanding, vulnerable and painful but it is the only promising passageway.

The symbol of the ram in Abraham's story provides the insight that during the growing up process we actually lose our children. The ram, observed by Abraham, is so tangled in the bushes that he cannot save himself. Thus, Abraham can catch him and offer him as a sacrifice. In the fragile ram we can easily recognize the image of Isaac as a child. However, at this juncture, Isaac is no longer a child. This child image of Isaac has existence only through his father's nostalgia, which needs to be burned and offered to God so that Abraham does not kill his adult son.

During our children's growing up process, often, memories come to mind when our "children" were still children. We remember how they were pleasant and playful, obedient and kind. With gratitude, we need to burn up this image, or in other words, we need to finally and completely relinquish this image. Our children will never be like this again. We are grateful to God for all childhood moments, and now, we offer them to God. However, we should not use these childhood memories as a reproach because the children have changed ${ }^{47}$.

47 Adolescents are literally allergic to hear a remark like: "When you were a child you were such a sweet good boy/good girl and now you are unbearable". A. G. Caissy, Early Adolescence: Understanding the 10 to 15 Year Old. New York - London 1994, Plenum Press, p. 62. 
Along with blocking the child's image of Isaac, Abraham sacrifices his personal (egoistic) plans and aspirations, which have been connected with Isaac ${ }^{48}$. Even if our vision has the most noble-minded desires and we wish to intertwine our children's future into it, this results in the degradation of their lives, and our good intentions simply become means to achieve and realize our own plans. Aided by the symbol of the ram, Abraham burns this aspect of his own "immortality". He completely surrenders it, as did Abel who offered his sacrifice to God.

All three aspects of Abraham's sacrifice: permission for growing up, the renouncement of the abuse of child images and the renouncement of using his child to achieve his own desires and plans - are connected with overcoming possessiveness. The quality and sustainability of education surfaces, most prominently, through the growing up process. During this process we are challenged to the innermost core of our being which includes sacrificing our firstborn to God. God can "consume" only the "first-borns" and transform them, like Abel's smoke, which gives meaning to our existence and we are able to admire the growth of new life.

Abraham's sacrifice indicates that, no matter how dedicated we are, God is not satisfied with partial religious answers. God requires a holistic and existential response in faith, which can be the fruit only of an adult, mature and responsible communication. In this context, Abraham's sacrifice is a test of his and our adulthood and maturity ${ }^{49}$.

12. Although Abraham's entire life and activities are imbued with faith we see in this story of reflection the painful process regarding the relationship between son and father. The latter recognizes himself not only as Isaac's father, but more strongly, as "father of the faith" or "father of the faithful" Abraham's memory that he experiences it as a special place of God's grace and love ${ }^{51}$. While looking at the place of the conflict, Abraham understands how God has educated him. Despite the pain while looking at his adult and independent son, he discovers the power of faith and God's goodness. Thus we can also expect

48 N. J. Cohen, Self, Struggle \& Change: Family Conflict Stories in Genesis and Their Healing Insights for Our Lives, Woodstock1995, Jewish Lights Publishing, p. 80.

49 N. J. Cohen, Self, Struggle \& Change: Family Conflict Stories in Genesis and Their Healing Insights for Our Lives, Woodstock1995, Jewish Lights Publishing, p. 90.

50 L. Powell, W. R. Self, Holy Murder: Abraham, Isaac, and the Rhetoric of Sacrifice, Lanham - Boulder - New York - Toronto - Plymouth 2007: University Press of America, p. 50.

51 Abraham named that place "The Lord Will Provide". And even now people say, "On the mountain of the Lord it will be provided". Gen $22: 14$. 
a second call from God, which becomes the basis for a relaxed and very optimistic vision toward the future ${ }^{52}$.

In this thoughtful reflection, Abraham again feels that God did not want to take his son away from him, but rather that God wanted to allow Isaac an independent and responsible life. It is precisely because God did not want to take Isaac that Abraham could now hand him over with the hope, that in the growing up process, he does not head toward nothingness, but rather toward God who is the Creator, Lord and guardian of life ${ }^{53}$. After this test, Abraham believes that Isaac, if he becomes independent, is in God's hands - in good hands. In the words of Jesus, we can say that Isaac landed "in my Father's house" (Lk 2:49).

At first glance, it seems that Abraham's insights are understandable and his decisions logical. However, from the perspective of the nature and purpose of biblical texts just the educational and psychological dimension would be too one-sided and superficial if the religious dimension of the story is ignored. In spite of logic, without his faith, Abraham would not have been able to make such decisions and take such actions to save lives. Religious communication with God (faith) does not give him only meaningful insights but also hope, motivation, and courage. Despite a high level of uncertainty and drama Abraham never criticizes either his son or God. His communication is always positive and his sensibility to religious dimensions decisively influences his way of solving problems on an immanent level. God did not train Abraham in a way that he would know ahead of time how the process would end. If Abraham's faith had been weaker, he would have moved away from God, and if his fear had increased in a way that Abraham would have wanted to take the whole situation into his own hands, the story would probably have had a different ending as it often happens in real life. Abraham is

52 The Lord's angel called out from heaven a second time: You were willing to offer the Lord your only son, and so he makes you this solemn promise, "I will bless you and give you such a large family, that someday your descendants will be more numerous than the stars in the sky or the grains of sand along the beach. They will defeat their enemies and take over the cities where their enemies live. You have obeyed me, and so you and your descendants will be a blessing to all nations on earth". Gen 22:15-18.

53 A. Höfer, Gottes Wege mit den Menschen: Ein gestaltpädagogisches Bibelwerkbuch, München 1993, Don Bosco Verlag, p. 121. 
not the father of faith because he allowed God to torture him, but because both father and son survived on a faith basis ${ }^{54}$.

By the power of faith, Abraham sets up his concrete future ${ }^{55}$. Now, Isaac is sufficiently independent that he can grow whilst Abraham, as a father, can diminish. In the eyes of each other, they both grow. While on the mountain, Abraham and Isaac's conflict-free and unburdened relationship deepened through their growing up process. Still, time will be necessary to allow them to process and reflect upon their new insights in order to be able to live out of them.

When we raise children to independence we are still far from solving all our problems and difficulties. Often the hardest part remains ahead of us. We (parents) need to meet ourselves anew and find our new life space within our marriage. After we no longer work for our children and when, for instance, our grandchildren are taken from us, we can no longer escape. Considering the biological and psychological changes connected to our age, a timely redefinition of our marriage and our marital relationship is required in order to bring new vitality into a slightly "dehydrated" life-space ${ }^{56}$. Considering such challenges in our reality, Abraham's story is much too complex to expect it to have had a happy ending as in a naive film script.

Despite God's promise, following the testing period, Abraham feels strangely alone. From the perspective of relationships, his life is marked more by demolition and torn relationships than by building ${ }^{57}$. First, he was torn from his own father, then, he was separated from Lot. After the first signs of success and fertility he had to send away Hagar and Ishmael. For a period of time, he even lost contact with Isaac. Life with his wife was a life of conflict and now, again they live separately. His wife is living in Hebron in the land of Canaan, where after some time, in Abraham's absence she dies (Gen 23:2-4).

Abraham's feelings of loneliness increase not only because of the recent test with Isaac but also because of the news of his wife's death. In this context the Bible rudely publishes an idyllic report regarding the large family of his brother Nahor (Gen

54 L. Powell, W. R. Self, Holy Murder: Abraham, Isaac, and the Rhetoric of Sacrifice, Lanham - Boulder - New York - Toronto - Plymouth 2007: University Press of America, p. 20.

55 Abraham and Isaac went back to the servants who had come with him, and they returned to Abraham's home in Beersheba. Gen 22:19.

56 E. J. Loder, The Logic of the Spirit: Human Development in Theological Perspective, San Francisco 1998, Jossey-Bass Publishers, p. 285-286.

57 L. Powell, W. R. Self, Holy Murder: Abraham, Isaac, and the Rhetoric of Sacrifice, Lanham - Boulder - New York - Toronto - Plymouth 2007: University Press of America, p. 25. 
$22: 20-24)$. All this shows how deep, radical and rigorous the Bible is at opening fundamental life issues. At the same time, when Abraham feels and experiences how - despite of or maybe precisely because of his cooperation with God - his life collapses and that he has no success, he sees in his brother the opposite of his catastrophic feelings.

In fact, the power of faith, intensive and confidential communication with God, the power of prayer and blessing donot result in Abraham's gathering of God's privileges and having a chance to avoid life difficult challenges but in his capacity to endure even the most horrible and painful situations. Abraham is neither upset nor hindered in his personal growth, given the strange dichotomy between "success and blessing": when blessing promises success but actually brings failure and when, at the same time, with human eyes, he sees successful people who do not deserve success.

After the death of his wife Sarah, Abraham, who "was already strong in years" (Gen 24:1), recommits to his son, and in accordance with the customs and rules of that time, and with the help of servants, begins to arrange Isaac's marriage. However, it still remains a painful realization that, on the mountain, in the province Moriah, a major insurmountable intergenerational conflict between Abraham and Isaac occurred, and according to the biblical text, resulted in a lack of communication, which endured until the end of life $\mathrm{f}^{58}$. Yet again, Abraham overcomes the limits of human capacities and in spite of Isaac's resentment and grudges, pronounces his "Fiat": "Here I am, my son" - an act of unconditional love.

Until Abraham's death, Isaac continues to be the most precious gift to his father and Abraham also takes care of Isaac's material needs (Gen 25:5-6). Despite his father's constant efforts, mutual reconciliation between Abraham and his son occurs only after Abraham's death at the grave. Interestingly enough, Abraham was buried, alongside his wife Sarah (Gen 25:8-10), by both sons, Isaac and Ishmael. In a conflict-free atmosphere the whole family gathers for the first time at the grave of their parents.

58 Isaac's question: "Where is the lamb for the sacrifice?" And Abraham's answer: "My son, God will provide the lamb", are the last written words, which Abraham and Isaac exchange. L. Powell, W. R. Self, Holy Murder: Abraham, Isaac, and the Rhetoric of Sacrifice, Lanham - Boulder - New York - Toronto - Plymouth 2007: University Press of America, p. 18. 


\section{Bibliography}

Benyoetz E., Keine Macht becherscht die Ohnmacht, in: B. Greiner, B. Janowski, H. Lichtenberger (Eds.), Opfere deinen Sohn!, Tübingen 2007, Francke Verlag, p. 109-134.

Caissy A. G., Early Adolescence: Understanding the 10 to 15 Year Old. New York - London 1994, Plenum Press.

Cohen N. J., Self, Struggle \& Change: Family Conflict Stories in Genesis and Their Healing Insights for Our Lives, Woodstock 1995, Jewish Lights Publishing.

Cohen N. J., Voices from Genesis: Guiding Us Through the Stages of Life, Woodstock - Vermont 1998, Jewish Lights Publishing.

Gerjolj S., Živeti, delati, ljubiti, Ljubljana 2009, Celjska Mohorjeva družba.

Hartley E. J., New International Biblical Commentary: Genesis, Peabody, Massachusetts \& United Kingdom 2000, Hendrickson Publishers, Paternoster Press.

Höfer A., Gottes Wege mit den Menschen: Ein gestaltpädagogisches Bibelwerkbuch, München 1993, Don Bosco Verlag.

Krašovec J., Nagrada, kazen in odpuščanje: Mišljenje in verovanje starega Izraela v luči grških in sodobnih pogledov, Ljubljana1999, Slovenska akademija znanosti in umetnosti.

Loder E. J., The Logic of the Spirit: Human Development in Theological Perspective, San Francisco 1998, Jossey-Bass Publishers.

McGee J. V., Genesis: Chapters 16-33, Nashville 1991, Thomas Nelson.

Powell L., Self W. R., Holy Murder: Abraham, Isaac, and the Rhetoric of Sacrifice, Lanham - Boulder - New York - Toronto - Plymouth 2007, University Press of America.

Schulweis H., For those who cant believe, New York 1994, HarperCollins.

Vertot, N., Ob mednarodnem dnevu družin, in: Rebublika Slovenija, Statistični urad Rebublike Slovenije, http://www.stat.si/novica_prikazi.aspx?id=1617 (07.03.2014).

Walton H. J., The NIV Application Commentary: From biblical text ... to contemporary life, Grand Rapids, Michigan 2001, Zondervan.

Willmes B., Die Prüfung Abrahams nach Gen 22,1-19, in: H. Hoping, J. Knop, T. Böhm (Eds.), Die Bindung Isaaks. Paderborn - München - Wien - Zürich 2009, Ferdinand Schöningh, p. 39-59. 